Article

\title{
Performic Acid Controls Better Clostridium tyrobutyricum Related Bacteria than Peracetic Acid
}

\author{
Maximilian Mora ${ }^{\dagger}$, Anna-Maria Veijalainen ${ }^{*}$ and Helvi Heinonen-Tanski \\ Department of Environmental and Biological Sciences, University of Eastern Finland, POB 1627, 70211 Kuopio, \\ Finland; maximilian.mora@medunigraz.at (M.M.); helvi.heinonentanski@uef.fi (H.H.-T.) \\ * Correspondence: anna-maria.veijalainen@uef.fi; Tel.: +358-403552478 \\ † Current address: Department for Internal Medicine, Medical University of Graz, Auenbruggerplatz 15, \\ 8036 Graz, Austria.
}

Received: 28 September 2018; Accepted: 6 November 2018; Published: 9 November 2018

check for updates

\begin{abstract}
Clostridia are anaerobic spore-forming bacteria, which degrade carbohydrates to butyric acid, carbon dioxide, hydrogen and other compounds. These bacteria are commonly found in feces of ruminants, from where they can enter to udders and milk via manure or fodder. This study was done to find a sustainable sanitation method to control the resistant clostridial spores as they are difficult to control in the food processing industry. Clostridia spoil cheeses and other dairy products, and thereby increase the carbon footprint of products and cause economical losses in the dairy industry. The efficacy of two organic peroxides; peracetic acid (PAA) and performic acid (PFA) was tested against 30 clostridia strains isolated from cattle slurry, silage, or spoiled cheeses. PAA, at a concentration of $220 \mathrm{mg} \mathrm{L}^{-1}$, only eliminated 6/30 clostridia strains, whereas PFA totally eliminated $26 / 30$ clostridia strains at a concentration of $120 \mathrm{mg} \mathrm{L}^{-1}$. PFA therefore seems to be a more potent disinfectant than the more commonly used PAA. PFA is an effective disinfectant against Clostridium tyrobutyricum and other resistant clostridia at $120 \mathrm{mg} \mathrm{L}^{-1}$ for 5-10 min contact time at room temperature.
\end{abstract}

Keywords: cheese spoiling; dairy industry; disinfection; peracids; spore-forming bacteria; sustainable sanitation

\section{Introduction}

Clostridium tyrobutyricum and related spore-forming bacteria live in soils, slurry and intestines of humans and other animals. These bacteria can also spoil silage, which reduces its nutritional value [1] and thus causes economic losses for farmers. The spoilage process of silage can be controlled by preservation compounds such as formic acid or acetic acid [2] or by favoring lactic acid bacteria fermentation [3]. In addition, ruminants can get vegetative cells and spores of $\mathrm{Cl}$. tyrobutyricum from soiled grass and the animals can then transmit these bacteria to feces, which can contaminate teats. The careful cleaning of cow teats before milking reduces up to $99 \%$ of $\mathrm{Cl}$. tyrobutyricum or Bacillus cereus numbers and thus, these spore-forming bacteria can contaminate cow milk [4] or ewe milk [5] and pose a genuine problem in milk processing [6].

Vegetative clostridia and their spores can contaminate tanks, pipes, valves and other surfaces in the dairy industry. The controlling of clostridia in dairy is difficult because clostridia enter via milk and their spores survive during the pasteurization process. The risk of spoilage is even greater when manufacturing hard or semi hard cheeses, due to a long ripening time. During this process, clostridia can grow and produce vomit-smelling butyric acid, acetic acid, hydrogen and carbon dioxide. These gases break down the structure of cheese by so-called late blowing and thereby spoil it totally, which causes enormous economic losses for the dairy industry [7] and may even inflict sustained 
damage upon the value of a certain brand of dairy products. Due to the vomit smell, there is no use for such spoiled cheese. Thus, this spoilage means wasted natural resources, remembering that each $\mathrm{kg}$ of cheese may need more than $10 \mathrm{~L}$ of milk, depending on their protein, fat and dry matter contents. Life cycle assessment analysis has shown that the environmental impact could be reduced by minimizing the wastage of cheese during manufacturing [8].

Lactobacilli and some related bacteria inhibit the growth of $\mathrm{Cl}$. tyrobutyricum in milk by producing different antibiotic compounds [9-11]. Similarly, nitrite salts and lysozyme enzyme can reduce or inhibit the growth of clostridia. They are therefore used in specific cheese processes [11-13]. These inhibitory compounds also have potential disadvantages. Spoiled cheese mass can contain many different microorganisms. For instance, nitrate-reducing bacteria can degrade added nitrate to nitrite and nitrosoamines, which increase the risk of gastric cancer [14]. The microorganisms present can also reduce the concentrations of added lysozyme or antibiotic compounds produced by lactic acid bacteria [13]. On the other hand, the residual concentrations of lysozyme isolated from eggs may cause allergenic reactions among egg-allergic persons [13]. It is also important to notice that there are traditional cheese makers who do not allow the addition of any enzymes, nitrate or bacteria in their "protected designation of origin" cheeses [15]. The sterilization of milk would reduce the spore-forming bacteria but this is not done because heat changes the chemical composition of milk and it is expensive. Thus, it is important to find new sustainable sanitation methods to control these bacteria in dairy industrial sites if there has been contamination caused by butyric acid producing clostridia.

Peracid disinfectants are safer than chlorine to the environment because their degradation products are just water and oxygen. The mode of action of peracids, such as peracetic acid (PAA) and performic acid (PFA) is based on their high oxidation ability. These acids have been found to be effective against many microbial groups including different $\mathrm{Cl}$. perfringens strains and related bacteria in wastewater [16-18] or on laboratory instruments $[19,20]$. All organic, dirty material possibly present in food industrial tanks, valves or pipes after process, may consume peracids. Therefore, the amount of sanitation compound must be high enough because even one clostridial cell can serve as an inoculum for a new contamination in industry. Generally, the disinfection efficiency of PFA is higher than that of PAA. It has been reported that the proportion of enteric clostridia increases when PAA is used as a disinfectant in wastewater treatment, as PAA sensitive non-spore forming microorganisms are destroyed by PAA, but PAA resistant clostridial spores can survive in these conditions [21].

We do not know of any papers where the disinfection efficiency of PAA or PFA has been studied against $\mathrm{Cl}$. tyrobutyricum or other resistant clostridia, which are difficult to control in the food processing industry. Therefore, the aim of this work was to study whether PAA or PFA can efficiently control $\mathrm{Cl}$. tyrobutyricum and other clostridia so that these compounds could be used in dairy and other food processing industries to disinfect production machines and areas.

\section{Materials and Methods}

Clostridial cultures used were obtained from DSM (Deutsche Sammlung von Mikroorganismen, Germany) or NCIMB (National Collection of Industrial, Marine and Food Bacteria, UK) collections or were isolated by us. The collection strains had been isolated from spoiled cheeses and our own isolates from silage grass or cattle slurry [22]. Ten collection strains and one of our own isolates were characterised as $\mathrm{Cl}$. tyrobutyricum, seven isolates as $\mathrm{Cl}$. propionicum like, four isolates as Cl. malenominatum, and eight isolates were unidentified strains [23]. Clostridial cultures were cultivated in Reinforced Clostridia Medium (RCM, Difco) containing $33 \mathrm{~g}$ organic compounds and $5 \mathrm{~g} \mathrm{NaCl}$ per liter. The RCM tubes were heated before use to destroy the residual oxygen. Incubations were carried out in anaerobic jars (Oxoid jars with Oxoid reagents) at $37{ }^{\circ} \mathrm{C}$ for 14 days and then stored at $4{ }^{\circ} \mathrm{C}$ for two or three months.

Peracetic acid (PAA) was obtained from Kemira, Oulu, Finland as either $34 \%$ or $40 \%$ solutions. The exposure dilutions of PAA were $30 \mathrm{mg} \mathrm{L}^{-1}, 60 \mathrm{mg} \mathrm{L}^{-1}, 110 \mathrm{mg} \mathrm{L}^{-1}$ and $220 \mathrm{mg} \mathrm{L}^{-1}$ in sterile water. Unstable performic acid (PFA) was synthesized for each experiment separately as an approximately 
$1 \%$ solution by mixing equal volumes of ice-cold $15 \%(w / v)$ formic acid, and $35 \%(w / v)$ hydrogen peroxide (both from Kemira, Finland). These were mixed for $17-18 \mathrm{~h}$ in an ice bath kept in a fume hood. The PFA concentration was determined by ceric sulphate titration for hydrogen peroxide and by iodometric thiosulphate titration for peroxy acids as described earlier [17]. The exposure dilutions of PFA were $30 \mathrm{mg} \mathrm{L}^{-1}, 60 \mathrm{mg} \mathrm{L}^{-1}$ and $120 \mathrm{mg} \mathrm{L}^{-1}$ in sterile water.

The final dilutions for both PAA and PFA were done less than one hour before each experiment. The control experiments were done with sterile water without peracids. The exposure peracid solutions and the controls $(5 \mathrm{~mL})$ were pipetted into sterile test tubes and then inoculated with $0.1 \mathrm{~mL}$ of bacterial suspensions. All 30 strains were exposed to both peracids for $5 \mathrm{~min}$ at $20 \pm 1^{\circ} \mathrm{C}$. Four $\mathrm{Cl}$. tyrobutyricum and six other clostridia strains were also exposed for $10 \mathrm{~min}$ because these strains had some resistance against PFA in a 5 min exposure time. Both the 2-3 month, and 14 day old cultures contained both vegetative cells and spores [22,23]. The exposures were stopped and disinfection efficiencies were confirmed by inoculating $0.1 \mathrm{~mL}$ of the exposed bacterial suspensions to $10 \mathrm{~mL}$ of Reinforced Clostridia Medium in test tubes, assuming that the rich organic matter of the medium would soon consume the possible residues of PFA or PAA. The inoculated test tubes were incubated at $37^{\circ} \mathrm{C}$ for 14 days in anaerobic jars.

The turbidity developed during incubation was recorded as growth, meaning that the peracid exposure had not destroyed all clostridia in the corresponding tube. Clear, non-turbid medium (like non-inoculated medium) was recorded as total inhibition, meaning that peracid had destroyed all cells. All tests were done in four replicate tubes so that the results could be between $0-4$, where 0 means turbid growth in all four replicate test tubes i.e., the growth was not inhibited in any tubes, and 4 means no growth in any of the replicate tubes i.e., total inhibition of growth. In some cases, the possible turbidity was very weak, yielding an ambiguous result. The experiment was then repeated.

Statistical analyses were conducted using IBM SPSS Statistic 21. A non-parametric Kruskal-Wallis test with a pairwise comparison was used to assess the statistically significant differences among the inhibitory effects (no growth) of disinfectants with tested concentrations $(p<0.05)$. All species were tested together and one by one. The differences between species in their sensitivity to PAA or PFA was tested with the same non-parametric test with a pairwise comparison. A Related-Samples Wilcoxon Signed Rank Test was used to test the statistically significant differences between 5 and $10 \mathrm{~min}$ treatment times on the growth of clostridia after treatment with different PAA and PFA concentrations $(p<0.05)$. If the growth test was done twice, the average result was used in the statistical analysis.

\section{Results}

All Clostridium strains showed growth with rich turbidity and precipitation in all four control tubes. Thus, the inoculum of all strains had contained enough vegetative cells for all tests. Peracetic acid (PAA) and performic acid (PFA) had very different disinfection abilities, as can be seen from Table 1 , which shows the efficacy of peracids in the four replicate test tubes $(4=$ no growth in any tube and $0=$ growth in all tubes). The inhibition of growth caused by 30,60 and $120 \mathrm{mg} \mathrm{L}^{-1}$ PFA were significantly higher than those caused by 30,60, 110 or $220 \mathrm{mg} \mathrm{L}^{-1}$ PAA $(p<0.05$ in Kruskal-Wallis test with pairwise comparison). The statistically significant difference in sensitivity is shown with different letters in Table 1 within the Clostridium types of $\mathrm{Cl}$. tyrobutyricum, $\mathrm{Cl}$. propionicum like, Cl. malenominatum and unidentified clostridia.

Table 1 shows that $30 \mathrm{mg} \mathrm{L}^{-1}$ PAA did not inhibit any Clostridium strains tested, and only a few strains were inhibited at 60,110 or $220 \mathrm{mg} \mathrm{L}^{-1}$ PAA without any significant differences with those of $30 \mathrm{mg} \mathrm{L}^{-1}$ PAA in the pairwise comparisons $(p>0.05)$. All $\mathrm{Cl}$. tyrobutyricum strains were resistant to all PAA concentrations tested up to $220 \mathrm{mg} \mathrm{L}^{-1}$. One $\mathrm{Cl}$. propionicum like, three $\mathrm{Cl}$. malenominatum, and two unidentified clostridia showed some sensitivity to concentrations of $60-220 \mathrm{mg} \mathrm{L}^{-1}$ PAA, although the differences between PAA concentrations were not significant in the pairwise comparison $(p>0.05$, Table 1$)$. The PAA-resistance of $\mathrm{Cl}$. tyrobutyricum strains were significantly higher than those of $\mathrm{Cl}$. propionicum likes, $\mathrm{Cl}$. malenominatum, or unidentified clostridia $(p<0.05)$. 
On the contrary, even $30 \mathrm{mg} \mathrm{L}^{-1}$ of PFA inhibited, at least partly, 24 of 30 Clostridium strains but the remaining six strains were resistant to this concentration (Table 1). When the concentrations of PFA increased there was more sensitivity to PFA. In addition, all 30 strains showed at least some sensitivity to $120 \mathrm{mg} \mathrm{L}^{-1}$ of PFA, and the disinfection caused by this concentration was significantly higher than those caused by lower PFA concentrations $(p<0.05)$. The strains of $\mathrm{Cl}$. malenominatum were significantly more sensitive to PFA than the strains of $\mathrm{Cl}$. tyrobutyricum or the unidentified clostridia $(p<0.05)$. However, there were no significant differences in PFA sensitivity between Cl. propionicum like and the other Clostridium types ( $p>0.05)$. Even $30 \mathrm{mg} \mathrm{L}^{-1}$ of PFA was effective against $\mathrm{Cl}$. malenominatum and $\mathrm{Cl}$. propionicum like, and there were no significant differences between PFA concentrations ( $p>0.05$, Table 1$)$. In other Clostridium types tested, the higher PFA concentrations inhibited the growth significantly better than the lower concentrations.

Table 1. Number of test tubes out of 4 without clostridial growth (totally disinfected) after exposed to peracids for $5 \mathrm{~min}$. The strains were 2-3 months old. Different letters indicate a statistically significant difference (non-parametric Kruskal-Wallis test with pairwise comparison, $p<0.05$ ) in the sensitivity to disinfectant within different Clostridium types.

\begin{tabular}{|c|c|c|c|c|c|c|c|c|}
\hline \multirow{2}{*}{ Clostridium Types } & \multirow{2}{*}{ Strains } & \multicolumn{4}{|c|}{$\begin{array}{l}\text { Peracetic Acid (PAA) } \\
\mathrm{mg} \mathrm{L}^{-1}\end{array}$} & \multicolumn{3}{|c|}{$\begin{array}{l}\text { Performic Acid (PFA) } \\
\text { mg L }^{-1}\end{array}$} \\
\hline & & 30 & 60 & 110 & 220 & 30 & 60 & 120 \\
\hline \multirow{12}{*}{ Cl. tyrobutyricum } & & a & a & $\mathrm{a}$ & $\mathrm{a}$ & $\mathrm{b}$ & $\mathrm{b}$ & $\mathrm{c}$ \\
\hline & DSM-663 & 0 & 0 & 0 & 0 & 3 & 3 & 3 \\
\hline & DSM-1460 & $\mathrm{nt}^{1}$ & 0 & 0 & 0 & 0 & 2 & 4 \\
\hline & DSM-2637 & nt & 0 & 0 & 0 & 4 & 3 & 4 \\
\hline & NICMB-701790 & 0 & 0 & 0 & 0 & 2 & 4 & 3 \\
\hline & NICMB-701715 & nt & 0 & 0 & 0 & 2 & 0 & 4 \\
\hline & NICMB-701753 & 0 & 0 & 0 & 0 & 1 & 4 & 3 \\
\hline & NICMB-701754 & nt & 0 & 0 & 0 & 1 & 1 & 4 \\
\hline & NICMB-701755 & 0 & 0 & 0 & 0 & 0 & 0 & 4 \\
\hline & NICMB-701756 & 0 & 0 & 0 & 0 & 2 & 3 & 4 \\
\hline & NICMB-701757 & 0 & 0 & 0 & 0 & 4 & 3 & 4 \\
\hline & HA-56 & 0 & 0 & 0 & 0 & 4 & 4 & nt \\
\hline \multirow{8}{*}{ Cl. propionicum like } & & a & $\mathrm{a}$ & $\mathrm{a}$ & $\mathrm{a}$ & $\mathrm{ab}$ & $\mathrm{b}$ & $b$ \\
\hline & PP-1 & nt & 0 & 0 & 0 & 2 & 4 & 4 \\
\hline & HL-17 & $\mathrm{nt}$ & 0 & 0 & 0 & 1 & 2 & 3 \\
\hline & KI-12 & 0 & 0 & 0 & 0 & 0 & 2 & 3 \\
\hline & KA-4 & nt & 0 & 0 & 0 & 3 & 4 & 4 \\
\hline & HA-13 & 0 & 0 & 0 & 0 & 2 & 3 & 3 \\
\hline & HA- $18^{2}$ & nt & nt & 0 & 0 & 3 & 3 & 4 \\
\hline & HA-19 & $\mathrm{nt}$ & 4 & 4 & 4 & 4 & 4 & 4 \\
\hline \multirow{5}{*}{ Cl. malenominatum } & & a & $\mathrm{a}$ & $\mathrm{ab}$ & $a b c$ & $\mathrm{bc}$ & c & c \\
\hline & 222-IIIa & 0 & 0 & 0 & 3 & 4 & 4 & 4 \\
\hline & 222-IIIlb & 0 & 0 & 2 & 4 & 4 & 4 & 4 \\
\hline & HL-54 & 0 & 0 & 0 & 0 & 2 & 4 & 4 \\
\hline & HL-55 & $\mathrm{nt}$ & 0 & 3 & 2 & 3 & 4 & 4 \\
\hline \multirow{9}{*}{ Unidentified clostridia } & & a & $\mathrm{a}$ & a & $\mathrm{a}$ & $\mathrm{ab}$ & $\mathrm{bc}$ & $\mathrm{c}$ \\
\hline & HL-27 & nt & 0 & 0 & 0 & 0 & $0(2)^{3}$ & 4 \\
\hline & HL-22 & 0 & 0 & 0 & 0 & 0 & 4 & 4 \\
\hline & HL-56 & nt & 0 & 0 & 0 & 2 & 3 & 4 \\
\hline & NU-7 & 0 & 0 & 0 & 0 & 0 & $1(2)^{3}$ & 4 \\
\hline & PP-51 & 0 & 0 & 0 & 0 & 3 & $3(2)^{3}$ & 4 \\
\hline & $\mathrm{Pt}-25$ & nt & 0 & 0 & 0 & 3 & 3 & 4 \\
\hline & HA-14 & $\mathrm{nt}$ & nt & 1 & 4 & 3 & 3 & 4 \\
\hline & PP-24 & nt & 3 & 4 & 4 & 4 & 4 & 4 \\
\hline
\end{tabular}

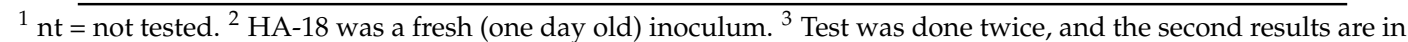
parenthesis. The average values (1 for HL-27, 1.5 for NU-7 and 2.5 for PP-51) were used in the statistical analysis. 
The disinfection efficiency of PFA was higher with 10 min than with 5 min exposure time (Table 2). This effect was significant in all cases at 30 or $60 \mathrm{mg} \mathrm{L}^{-1}$ PFA concentrations $(p<0.05$ Table 2$)$ except for $\mathrm{Cl}$. malenominatum, which already was highly inhibited at 5 min exposure time $(p>0.05$, Table 2). Only one strain out of 10 tested strains ( $\mathrm{Cl}$. malenominatum 222-IIIa) was inhibited with PAA more if the exposure time was $10 \mathrm{~min}$ instead of $5 \mathrm{~min}$, showing a significant difference only at $110 \mathrm{mg} \mathrm{L}^{-1}$ PAA concentration $(p<0.05)$.

Table 2. Number of test tubes out of 4 without clostridial growth (totally disinfected) after being exposed to PAA or PFA for 5 and $10 \mathrm{~min}$. The strains were 14 days old. The test was not done for the 20 strains found to be sensitive to PFA. Results of $30 \mathrm{mg} \mathrm{L}^{-1}$ are not given if $60 \mathrm{mg} \mathrm{L}^{-1}$ in $5 \mathrm{~min}$ had growth i.e., no disinfection effect.

\begin{tabular}{|c|c|c|c|c|c|}
\hline \multirow[b]{2}{*}{ Peracid } & \multirow{2}{*}{ Clostridium Type } & \multirow{2}{*}{ Strains } & \multirow{2}{*}{ Concentration $\mathrm{mg} \mathrm{L}^{-1}$} & \multicolumn{2}{|c|}{ Exposure Time } \\
\hline & & & & $5 \mathrm{~min}$ & $10 \mathrm{~min}$ \\
\hline \multirow{6}{*}{ PAA } & Cl. tyrobutyricum & $\begin{array}{l}\text { DSM-1460, NCIMB-701715, } \\
-701754 \text { and -701755 }\end{array}$ & 60,110 and 220 & 0 & 0 \\
\hline & Cl. propionicum like & PP-1, HL-17 and KA-4 & 60,110 and 220 & 0 & 0 \\
\hline & \multirow{3}{*}{ Cl. malenominatum } & \multirow{3}{*}{ 222-IIIa } & 60 & 0 & 2 \\
\hline & & & 110 & 0 & 4 \\
\hline & & & 220 & 3 & 4 \\
\hline & Unidentified clostridia & HL-27 and HL-22 & 60,110 and 220 & 0 & 0 \\
\hline \multirow{22}{*}{ PFA } & \multirow{10}{*}{ Cl. tyrobutyricum } & \multirow[t]{2}{*}{ DSM-1460 } & 60 & 2 & 3 \\
\hline & & & 120 & 4 & 4 \\
\hline & & \multirow[t]{2}{*}{ NCIMB-701715 } & 60 & 0 & 3 \\
\hline & & & 120 & 4 & 4 \\
\hline & & \multirow{3}{*}{ NCIMB-701754 } & 30 & 1 & 4 \\
\hline & & & 60 & 1 & 4 \\
\hline & & & 120 & 4 & 4 \\
\hline & & \multirow{3}{*}{ NCIMB-701755 } & 30 & 0 & 2 \\
\hline & & & 60 & 0 & 4 \\
\hline & & & 120 & 4 & 4 \\
\hline & \multirow{6}{*}{ Cl. propionicum like } & \multirow[t]{2}{*}{ PP-1 } & 30 & 2 & 3 \\
\hline & & & 60 and 120 & 4 & 4 \\
\hline & & \multirow{3}{*}{ HL-17 } & 30 & 1 & 4 \\
\hline & & & 60 & 2 & 4 \\
\hline & & & 120 & 3 & 4 \\
\hline & & KA-4 & 60 and 120 & 4 & 4 \\
\hline & Cl. malenominatum & 222-IIIa & 30,60 and 120 & 4 & 4 \\
\hline & \multirow{5}{*}{ Unidentified clostridia } & \multirow{3}{*}{ HL-27 } & 30 & 0 & 4 \\
\hline & & & 60 & $0(2)^{1}$ & 4 \\
\hline & & & 120 & 4 & 4 \\
\hline & & \multirow[t]{2}{*}{ HL-22 } & 60 & 2 & 4 \\
\hline & & & 120 & 4 & 4 \\
\hline
\end{tabular}

${ }^{1}$ Test was done twice, and the second results are in parenthesis. The average value (1 for HL-27) was used in statistical analysis.

\section{Discussion}

The major finding of the study was that PFA is a significantly more powerful disinfectant than PAA. In general, our results provide evidence of the increase of PFA efficacy at higher concentrations and/or longer exposure times. Thus, our work confirms the earlier results of wastewater disinfection experiments, where the exposure time for PFA could be less than 20 min in comparison with the $6 \mathrm{~h}$ exposure time needed for PAA [24]. However, a high PFA concentration with a long exposure time 
may increase the risk of corrosion [25]. More studies of PFA should be done to evaluate its use in the applications of different food processing industries with rather short time disinfections so that its registration as a disinfectant compound would take place. PFA is already known to be effective in cold temperatures [17], which is often needed in food processes.

The resistance of bacteria against peracids is known to be affected by temperature, peracid concentrations and organic matter (as casein or peptone), as these factors increase the degradation of peracids and thereby the formation of degradation products, such as peroxyls or hydroxyl radicals [26]. It has been found that the decay rate of PAA increases when the temperature increases from 20 to $30{ }^{\circ} \mathrm{C}$ and the concentration of organic matter in medium increases from 0 to $70 \mathrm{mg} \mathrm{COD} \mathrm{L}^{-1}$ [27]. If we would have a higher exposure temperature, the disinfection efficiency of PAA and PFA in the present work would possibly have been higher. The radicals formed in the decay process might have a major role in improving the disinfection ability [28]. Since PFA is more labile than PAA, it will decay more rapidly [25] and form more radicals. Therefore, PFA is a more powerful disinfectant than PAA.

The concentrations used in our study $\left(30-220 \mathrm{mg} \mathrm{L}^{-1}\right)$ for PAA and $\left(30-120 \mathrm{mg} \mathrm{L}^{-1}\right)$ for PFA were so high that the results cannot be well compared to earlier disinfection works, where peracid concentration was up to $10 \mathrm{mg} \mathrm{L}^{-1}$ in treated wastewater [26] or aquarium water [27]. Our inoculum of $0.1 \mathrm{~mL}$ could have contained up to $3.3 \mathrm{mg}$ organic matter, which was added to $5 \mathrm{~mL}$ of exposure solution, meaning that the solution's organic matter concentration was $660 \mathrm{mg} \mathrm{L}^{-1}$ if the organic matter, which was consumed by clostridial growth before exposure tests, was ignored. We did not measure the decay of PFA or PAA during the exposure of 5 or $10 \mathrm{~min}$, but there must have been some decay due to the high level of organic matter [26,27].

PFA has been estimated to be a cost-efficient option to replace PAA if the need for disinfectant is getting higher due to the increasing capacity of industrial plants, although it needs to be produced just before usage [29]. PFA, used in this study, was self-made with the reagent price around $15 €$ for $1 \mathrm{~kg}$ [24]. In our work, the production process work was rapid and trouble-free. However, it is highly recommended that a protective mask is used during work and that the work is done in a fume hood.

If the need for PFA is high and daily, there is a commercial PFA production and dosing unit available (i.e., Desinfix ${ }^{\circledR}$ Kemira, Finland with annual capital costs of 12,000 $€$ ), which decreases the risk of occupational hazards, which must be considered when producing highly reactive PFA [24]. This kind of unit may enable the utilization of this environmentally friendly PFA disinfectant to decrease economical losses caused by Clostridium tyrobutyricum and related spore-forming bacteria in the dairy industry.

\section{Conclusions}

Performic acid can efficiently control butyric acid producing clostridia even within an exposure time of $5-10 \mathrm{~min}$ at $20^{\circ} \mathrm{C}$ when its concentration is $30-120 \mathrm{mg} \mathrm{L}^{-1}$. A longer time would be more effective for PFA. On the contrary, although peracetic acid controlled within an exposure time of 5-10 min only a few of the clostridia strains studied even when its concentration was $220 \mathrm{mg} \mathrm{L}^{-1}$.

The use of PFA in the dairy industry could increase the sustainability of cheese production in large areas where milk production is the only possibility for agriculture due to the climate or rocky soils, since butyric acid producing bacteria can totally spoil hard and semi hard cheeses to harmful wastes. This spoiling could lead to the total loss of the relatively high carbon footprint of cheeses.

It is recommended that PFA should be registered as a disinfectant in cases where clostridia or other resistant organisms cause a serious risk, e.g., in food the processing industry.

Author Contributions: All authors (M.M., A.-M.V. and H.H.-T.) have contributed to the design of study, analysis of the data, and the writing and editing of the paper.

Funding: The EU ERASMUS program financed Maximilian Mora's work during laboratory research and was a part of the PhD Program-Molecular Medicine of the Medical University of Graz while writing the paper.

Acknowledgments: We thank Sirpa Martikainen for assisting with the laboratory work in UEF and Kemira, Oulu, Finland for providing reagents. 
Conflicts of Interest: The authors declare no conflict of interest. The funders had no role in the design of the study; in the collection, analyses, or interpretation of data; in the writing of the manuscript, or in the decision to publish the results.

\section{References}

1. Wen, A.Y.; Yuan, X.Y.; Wang, J.; Deast, S.T.; Shao, T. Effects of four short-chain fatty acids or salts on dynamics of fermentation and microbial characteristics of alfalfa silage. Anim. Feed Sci. Technol. 2017, 223, 141-148. [CrossRef]

2. Jonsson, A.; Lindberg, H.; Sundås, S.; Lingvall, P.; Lindgren, S. Effect of additives on the quality of big-bale silage. Anim. Feed Sci. Technol. 1990, 31, 139-155. [CrossRef]

3. Dunière, L.; Sindou, J.; Chaucheyras-Durand, F.; Chevallier, I.; Thévenot-Sergentet, D. Silage processing and strategies to prevent persistence of undesirable microorganisms. Anim. Feed Sci. Technol. 2013, 182, 1-15. [CrossRef]

4. Magnusson, M.; Christiansson, A.; Svensson, B.; Kolstrup, C. Effect of different premilking manual teat-cleaning methods on bacterial spores in milk. J. Dairy Sci. 2006, 89, 3866-3875. [CrossRef]

5. Arias, C.; Oliete, B.; Seseña, S.; Jiménez, L.; Palop, L.; Pérez-Guzmán, M.D.; Arias, R. Importance of on-farm management practices on lactate-fermenting Clostridium spp. spore contamination of total mixed ration of Manchega ewe feeding. Determination of risk factors and characterization of Clostridium population. Small Ruminant Res. 2016, 139, 39-45. [CrossRef]

6. Ruusunen, M.; Surakka, A.; Korkeala, H.; Lindström, M. Clostridium tyrobutyricum Strains Show Wide Variation in Growth at Different $\mathrm{NaCl}, \mathrm{pH}$, and Temperature Conditions. J. Food Protect. 2012, 75, 1791-1795. [CrossRef] [PubMed]

7. Brändle, J.; Domig, K.J.; Kneifel, W. Relevance and analysis of butyric acid producing Clostridia in milk and cheese. Food Control 2016, 67, 96-113. [CrossRef]

8. Berlin, J. Environmental life cycle assessment (LCA) of Swedish semi-hard cheese. Int. Dairy J. 2002, 12, 939-953. [CrossRef]

9. Klaenhammer, T. Genetics of bacteriocins produced by lactic acid bacteria. FEMS Microbiol. Rev. 1993, 12, 39-85. [CrossRef] [PubMed]

10. Rilla, N.; Martínez, B.; Delgado, T.; Rodríguez, A. Inhibition of Clostridium tyrobutyricum in Vidiano cheese by Lactococcus lactis ssp. lactis IPLA 729, a nisin Z producer. Int. J. Food Microbiol. 2003, 85, 23-33. [CrossRef]

11. Ávila, M.; Gomez-Torres, N.; Hernandez, M.; Garde, S. Inhibitory activity of reuterin, nisin, lysozyme and nitrite against vegetative cells and spores of dairy-related Clostridium species. Int. J. Food Microbiol. 2012, 172, 70-75. [CrossRef] [PubMed]

12. D'Incecco, P.; Gatti, M.; Hogenboom, J.A.; Bottari, B.; Rosi, V.; Neviani, E.; Pellegrino, L. Lysozyme affects the microbial catabolism of free arginine in raw-milk hard cheeses. Food Microbiol. 2016, 57, 16-22. [CrossRef] [PubMed]

13. Oliveira, R.B.A.; Margalho, L.P.; Nascimento, J.; Costa, L.E.O.; Portela, J.B.; Cruz, A.G.; Sant'Ana, Anderson, S. Processed cheese contamination by spore-forming bacteria: A review of sources, routes, fate during processing and control. Trends Food Sci. Technol. 2016, 57, 11-19.

14. Song, P.; Wu, L.; Guan, W. Dietary Nitrates, Nitrites, and Nitrosamines Intake and the Risk of Gastric Cancer: A Meta-Analysis. Nutrients 2015, 7, 9872-9895. [CrossRef] [PubMed]

15. Bisig, W.; Fröhlich-Wyder, M.-T.; Jakob, E.; Wechsler, D. Comparison between Emmentaler PDO and generic emmental cheese production in Europe. Aust. J. Dairy Technol. 2010, 65, 206-213.

16. Kitis, M. Disinfection of wastewater with peracetic acid: A review. Environ. Int. 2004, 30, 47-55. [CrossRef]

17. Heinonen-Tanski, H.; Miettinen, H. Performic acid as a potential disinfectant at low temperatures. J. Food Process Eng. 2010, 33, 1159-1172. [CrossRef]

18. Karpova, T.; Pekonen, P.; Gramstad, R.; Öjstedt, U.; Laborda, S.; Heinonen-Tanski, H.; Chávez, A.; Jiménez, B. Performic acid for advanced wastewater disinfection. Water Sci. Technol. 2013, 68, 2090-2096. [CrossRef] [PubMed]

19. Rutala, W.A.; Weber, D.J. New Disinfection and Sterilization Methods. Emerg. Infect. Dis. 2001, 7, 348-353. [CrossRef] [PubMed] 
20. Broda, D.M. The effect of peroxyacetic acid-based sanitizer, heat and ultrasonic waves on the survival of Clostridium estertheticum spores in vitro. Lett. Appl. Microbiol. 2007, 45, 336-341. [CrossRef] [PubMed]

21. Eramo, A.; Morales Medina, W.R.; Fahrenfeld, N.L. Peracetic acid disinfection kinetics for combined sewer overflows: Indicator organisms, antibiotic resistance genes, and microbial community. Environ. Sci. Water Res. Technol. 2017, 3, 1061-1072. [CrossRef] [PubMed]

22. Heinonen-Tanski, H.; Niskanen, E.M.; Mielonen, M.M.; Räsänen, H.; Valta, T.; Leinonen, P.; Rinne, K.; Joki-Tokola, E. Aeration improves the hygiene of cattle slurry and the hygiene of grass forage and silage. Acta Agric. Scand. Soil Plant 1998, 48, 212-221. [CrossRef]

23. Langó, Z.; Heinonen-Tanski, H. Occurrence of Clostridium tyrobutyricum in cattle slurry and fresh forage grasses. Bioresour. Technol. 1995, 53, 189-191. [CrossRef]

24. Chhetri, R.K.; Thornberg, D.; Berner, J.; Gramstad, R.; Öjstedt, U.; Sharma, A.K.; Andersen, H.R. Chemical disinfection of combined sewer overflow waters using performic acid or peracetic acid. Sci. Total Environ. 2014, 490, 1065-1072. [CrossRef] [PubMed]

25. Luukkonen, T.; Heyninck, T.; Rämö, J.; Lassi, U. Comparison of organic peracids in wastewater treatment: Disinfection, oxidation and corrosion. Water Res. 2015, 85, 275-285. [CrossRef] [PubMed]

26. Domínguez Henao, L.; Delli Compagni, R.; Turolla, A.; Antonelli, M. Influence of inorganic and organic compounds on the decay of peracetic acid in wastewater disinfection. Chem. Eng. J. 2018, 337, 133-142. [CrossRef]

27. Pedersen, L.-F.; Meinelt, T.; Straus, D.L. Peracetic acid degradation in freshwater aquaculture systems and possible practical implications. Aqua. Eng. 2013, 53, 65-71. [CrossRef]

28. Li, H.; Zhu, X.; Ni, J. Comparison of electrochemical method with ozonation, chlorination and monochlorammination in drinking water disinfection. Electrochim. Acta 2011, 56, 9789-9796. [CrossRef]

29. Luukkonen, T.; Pehkonen, S. Peracids in water treatment: A critical review. Crit. Rev. Environ. Sci. Technol. 2017, 47, 1-39. [CrossRef]

(C) 2018 by the authors. Licensee MDPI, Basel, Switzerland. This article is an open access article distributed under the terms and conditions of the Creative Commons Attribution (CC BY) license (http:/ / creativecommons.org/licenses/by/4.0/). 